\title{
LA TRANSFORMACIÓN DE LOS RECURSOS EXTRAORDINARIOS EN EL DERECHO PROCESAL BRASILEÑO*
}

Handel Martins Dias**

\begin{abstract}
Resumen
Por medio de investigación de la legislación nacional, literatura jurídica, jurisprudencia y utilización de la metodología participante para la interpretación del fenómeno jurídico y normativo, este trabajo estudia el recurso extraordinario y el especial en el derecho procesal brasileño. El objetivo primordial del estudio consistió en verificar la transformación que padeció esta clase de recurso en Brasil mediante la ampliación de la eficacia de las decisiones del Tribunal Supremo Federal y del Tribunal Superior de Justicia. Se constató que este cambio se incrementó con el nuevo Código Procesal Civil, editado en 2015, el cual torna precedentes vinculantes los juicios de mérito en los juzgamientos de recursos extraor-
\end{abstract}

Recibido: marzo 26 de 2016 - Aprobado: julio 26 de 2016.

* Artículo inédito.

Para citar el artículo: DIAS, Handel Martins. La transformación de los recursos extraordinarios en el derecho procesal brasileño. Revista del Instituto Colombiano de Derecho Procesal. No. 44, julio- diciembre. 2016. Bogotá: Instituto Colombiano de Derecho Procesal. pp. 223-249

* Abogado en Brasil. Doctor en Derecho Procesal por la Universidade de São Paulo. Magíster en Derecho Procesal por la Universidade Federal do Rio Grande do Sul. Especialista en Derecho Procesal Civil por la Universidade Federal do Rio Grande do Sul. Profesor de Derecho Procesal en los cursos de pregrado y maestría en Derecho en la facultad de derecho de la Fundação Escola Superior do Ministério Público. Investigador y coordinador de las actividades de investigación de la faculdad de derecho de la Fundação Escola Superior do Ministério Público. Profesor visitante en cursos de posgrados de diversas instituciones de enseñanza superior. Miembro del Instituto Brasileiro de Direito Processual. Email handel.dias@fmp.com.br.

ISSN 2346-3473 • pp. 223-249 • Julio - Diciembre de 2016 • Bogotá, D.C. - Colombia 
La transformación de los recursos extraordinarios en el derecho procesal brasileño

dinario y especial repetitivos y de recursos extraordinario y especial interpuestos contra los fallos dictados por los tribunales en incidentes de resolución de demandas repetitivas.

Palabras clave: writ of error, recurso extraordinario, recurso especial, jurisprudencia, casos repetitivos, eficacia, nuevo Código Procesal Civil, Brasil.

\begin{abstract}
By researching the national legislation, legal literature, jurisprudence and utilization of the participating methodology for the interpretation of the juridical and normative phenomenon, this paper study the extraordinary and special appeal within Brazilian procedural law. The main purpose of the study consisted in verify the transformation that suffered this kind of appeal in Brazil through the expanding of the effectiveness of the decisions of the Federal Supreme Court and the Superior Court of Justice. It was found that these transformations increased with the new Code of Civil Procedure, edited in 2015, which becomes binding precedents the merit decisions in trials of repetitive special and extraordinary appeals and in trials of extraordinary and interpose special appeals against judgements dictated by courts in resolution incidents of repetitive demands.
\end{abstract}

Key words: writ of error, extraordinary appeal, special appeal, jurisprudence, repetitive cases, effectiveness, new Code of Civil Procedure, Brazil.

\title{
Introducción
}

A pesar del hombre ser, según las palabras de Aristóteles, un animal político, que puede vivir sólo en sociedad, la interacción humana es forzosamente irascible. Ante este hecho inexorable resulta imprescindible la coordinación de las relaciones intersubjetivas y la existencia de mecanismos capaces de dirimir los conflictos de intereses que, de forma inevitable y permanente, surgen en la sociedad para que esta subsista o perdure de la manera más armoniosa posible. Precisamente de la correlación intrínseca que existe entre el Derecho y la sociedad, exaltada en el apotegma latino ubi societas, ibi ius, nace la necesidad de controlar el comportamiento social del hombre. Es por el Derecho, el medio más eficaz e importante de control social, que la sociedad busca congraciar los intereses individuales y, por ello, garantizar su buen funcionamiento y continuidad. En los países de civil law, la ley es el estándar objetivo del Derecho para la consecución de seguridad en las relaciones sociales. Es mediante la previsibilidad del Derecho en las normas jurídicas, plasmadas de fuerza coercitiva, y la institución de órganos destinados a promover el respeto y la aplicación de estas normas jurídicas, que el Estado previene y soluciona los conflictos 
de intereses, así como condiciona, directa o indirectamente, el comportamiento de las personas en la sociedad ${ }^{1}$.

Con todo, la naturaleza contingente del Derecho, la incompletitud de las normas, las antinomias, la ignorancia y la volición hacen que el afrontamiento de la ley y su interpretación divergente sean constantes en la vida en sociedad. Por esta razón es imprescindible que el Estado no sólo procure preservar la validez y la unidad del ordenamiento jurídico, sino que también disponga de herramientas capaces de garantizar ese desiderátum, incluso en relación a sí mismo, pues corrientemente es el responsable por maltrato al ordenamiento jurídico o por disenso en su interpretación. Como corolario del desarrollo de sus funciones desde su consagración como poder político autónomo e independiente, el poder judicial constituye la propia y principal institución para ejercer ese menester en el Estado contemporáneo. Por eso, a más de administrar la justicia, incumbe al poder judicial asegurar la autoridad y la uniformidad del ordenamiento, así como preservar los principios de legalidad e igualdad, sea por medio de cada proceso subjetivo en el cual se requiera la tutela jurisdiccional, sea a través de procedimientos específicos, como las acciones de control de constitucionalidad.

Es posible, todavía, que órganos del propio poder judicial afronten el ordenamiento jurídico y apliquen de forma incorrecta el derecho al caso o no observen las reglas del debido proceso en la resolución de la causa. Puede suceder, aun, que el poder judicial promueva, por sus innumerables órganos, disenso en torno de la aplicabilidad del ordenamiento jurídico en el ejercicio del poder jurisdiccional. Por esa razón que -una vez vencidos dos grados de jurisdicción, las cuales serían, en rigor, suficientes para los anhelos de los individuos y para el objetivo del Estado de pacificar con justicia - es común la existencia de una instancia específica con la función de celar el orden jurídico. Sirviéndose de la iniciativa de las partes, se pone a su disposición un recurso para que ingresen en una nueva y postrera instancia. $\mathrm{Al}$ defender sus intereses particulares, las partes pueden conducir posible violación

\footnotetext{
${ }^{1}$ Naturalmente, e incluso porque integra la propia noción de Estado soberano, el complejo de normas que constituyen el orden jurídico deben aplicarse a todos los individuos que componen la población del Estado, de modo que toda la comunidad social sea sometida a un mismo y único ordenamiento jurídico. Mientras tanto, para que el Derecho alcance debidamente sus intentos, no basta que el mismo ordenamiento jurídico tenga vigencia ante toda la población, pero que también sea armonioso, considerado en su totalidad y tenga idéntico significado para todos. Sólo entonces es posible, efectivamente, la determinación de las reglas de conducta que deberán ser observadas por los individuos, las cuales garantizan la seguridad en las relaciones sociales. Sin embargo, esa necesidad de unidad no existe solamente por el designio de impedir la inseguridad jurídica, fomentada por la incertidumbre del derecho subsiguiente de la propagación de sentidos discrepantes a las normas jurídicas. Como subraya Claus-Wilhelm Canaris, la unidad del ordenamiento pertenece a las exigencias éticas y jurídicas más fundamentales y radica en la propia idea de Derecho. La igualdad jurídica entre todos compone un principio basilar del Estado Democrático de Derecho y presupone la propia concepción de Derecho y de justicia.
} 
La transformación de los recursos extraordinarios en el derecho procesal brasileño

del ordenamiento jurídico o disenso jurisprudencial al conocimiento de una corte superior, para que se acojan la autoridad y la interpretación única de las normas jurídicas, primarias y secundarias. Constituyen recursos extraordinarios estos recursos de inherente función política, dirigidos a tribunales superiores en procesos subjetivos, con la función de primar por la validez y unidad del ordenamiento jurídico, dando cabo, de ese modo, a la inseguridad y a la incertidumbre acerca de los derechos y de los deberes abrigados en el derecho escrito ${ }^{2}$.

Los recursos extraordinarios tienen rasgos y contornos bastante característicos en cada sistema procesal. A pesar de que existen recursos extraordinarios hasta en los Estados unitarios, donde, por regla, los órganos jurisdiccionales son unificados y la fuente normativa de derecho es una, recursos de esta especie se muestran más importantes en los Estados que tienen la hechura federativa ${ }^{3}$. La repartición territorial de poder impulsa, de forma nefasta, la afronta al ordenamiento jurídico y la discordia en su aplicación por parte de los agentes políticos y por los ciudadanos en general. Ese cuadro es particularmente austero en el Estado Federal brasileño, una vez que tiene descentralización de estructura triple y organización judicial compleja, en las cuales coexiste una plétora de órganos jurisdiccionales federales

2 Los recursos de género extraordinario visan, primeramente, en la expresión consagrada por Piero Calamandrei, a la nomofilaquia. Protegen tan sólo de forma refleja y secundaria el derecho del recurrente, caso se constate que la decisión impugnada violó la ley o, en la hipótesis de disensión jurisprudencial, no le dio interpretación consentánea con el ordenamiento jurídico. Existen teorías que sostienen que la finalidad de los recursos extraordinarios es el atendimiento del interese jurídico de la parte (teoría de la preponderancia del interese de la parte) o, simultáneamente, este interese y el interese de protección y unidad del Derecho objetivo (teoría de la equivalencia de los fines de la casación). La dominante, y que se adopta en este estudio, es la teoría de la preponderancia de la unidad o teoría de la función iusunitaria, por la cual debe preponderar en este género de recurso la función nomofiláctica en desfavor del interese jurídico de las partes. Sobre esas teorías, véase KNIJNIK, Danilo. O recurso especial e a revisão da questão de fato pelo Superior Tribunal de Justiça. Rio de Janeiro: Forense, 2005. pp. 90 - 98.

3 Esta categoría de recurso no tiene por finalidad primordial la consecución de una decisión pretenciosamente más justa o la corrección de desaciertos de orden procesal, tareas propias de los recursos ordinarios. Aunque parezca, a primera vista, que no se coadunen con la función del Poder Judicial de componer los conflictos de interés de la manera más justa posible, los recursos extraordinarios no están disociados de los ideales de justicia. Al viabilizar la preservación de la autoridad y de la unidad del Derecho vigente, perpetran, innegablemente, la igualdad y, en consecuencia, la justicia en la esfera del interés general de la sociedad, más allá del ámbito del interés individual de las partes del proceso. Además, mediante la procedencia del recurso extraordinario, ya sea para que el propio tribunal superior corrija error de Derecho, ya sea para dictar iudicium rescindens con la finalidad de que el órgano inferior profiera nueva decisión al corregir el error in iudicando, se protege tanto los intereses de la sociedad como de las partes, puesto que conduce, de forma indirecta, a la justicia en el caso concreto. 
y estatales ${ }^{4}$. Por encima de todo, Brasil posee un territorio de dimensiones continentales, con diferencias físicas, económicas, humanas, culturales y sociales muy acentuadas. En los últimos años, en virtud del número invencible de procesos en los foros y tribunales brasileños, los recursos de género extraordinario han pasado por una gran mudanza en el sistema procesal. El presente ensayo se propone a estudiar precisamente esta transformación. Antes, a título propedéutico, es realizado un breve análisis del origen y de la evolución histórica del recurso extraordinario en el país. En seguida, es objeto de examen el régimen de los recursos extraordinarios en el orden constitucional vigente. Precediendo la conclusión, se investiga el sistema de los recursos con el nuevo Código Procesal Civil brasileño, en el cual se realza, en particular, la ampliación de la eficacia expansiva de los juicios.

\section{Origen y síntesis histórica del recurso extraordinario}

Ante la proclamación de la República en 1889, Brasil se desvinculó de la orientación europea y adoptó el sistema estadounidense como modelo estructural y funcional. Una de las consecuencias más sentidas fue la transformación del poder judicial, que, en fin, adquirió contornos institucionales de poder político y asumió definitivamente posición destacada en el Estado brasileño ${ }^{5}$. Esta nueva condición que granjeó el poder judicial se expresaba, sobre todo, en el papel que conquistó su órgano de cúpula en la defensa del orden jurídico. Incluso antes de ser promulgada la primera Constitución Republicana, mediante el Decreto 510, del 22 de junio de 1890, el Gobierno Provisorio instituyó una nueva corte para ocupar el ápice de la estructura judicial -el Tribunal Supremo Federal-, e introdujo un nuevo recurso extraordinario. A la vista de la adopción del federalismo, era imprescindible la existencia de un tribunal federal que, mediante juicios de recursos extraordinarios, preservase la autoridad y la entereza de la Constitución y de las leyes federales y garantizara el funcionamiento de la principiante forma de gobierno. De esa manera,

4 Desde la República, la organización político-administrativa de Brasil comprende los Estados, entidades subnacionales autónomas equivalentes a los departamentos de la República de Colombia. En este estudio se emplea el vocablo Estado y sus derivados cuando se refiere a esta unidad federativa de Brasil.

5 Emérito conocedor de los escritores angloamericanos y de la jurisprudencia de la Corte Suprema de los Estados Unidos de América, Rui Barbosa fue decisivo para la adopción del sistema estadounidense en Brasil. Al retratar la ideología que ha conducido al acogimiento de ese paradigma, la historiadora Lêda Boechat Rodrigues destaca la importancia que tuvo The american commonwealth, de James Bryce, publicado un año antes de la proclamación de la República en Brasil. Con las modificaciones introducidas por el tiempo, la obra trazaba la teoría y la práctica de las instituciones gubernamentales norteamericanas. También De la démocratie en Amérique tuvo grande influencia en el pensamiento de los políticos y juristas brasileños. En aquel final del siglo XIX, la obra maestra de Alexis de Tocqueville fue innúmeras veces citada en el Congreso Nacional y en escritos de autores de Derecho público.

ISSN 2346-3473 • pp. 223-249 • Julio - Diciembre de 2016 • Bogotá, D.C. - Colombia 
La transformación de los recursos extraordinarios en el derecho procesal brasileño

bajo la influencia del constitucionalismo norteamericano, se desdeñó el recurso de revista ${ }^{6}$ de la tradición luso-brasileña y se tomó el writ of error del Derecho angloamericano como modelo, con la traducción, casi literal, de, las disposiciones del Judiciary Act y de las leyes posteriores?

Consonante con el Decreto 510, tenido como auténtica constitución provisional de la República Brasileña, el nuevo recurso extraordinario era admisible contra las decisiones dictadas en última instancia en las justicias de los Estados, notablemente cuando contrariasen tratados y leyes federales o considerasen válidas leyes o actos de gobiernos estatales contrarios a la ley federal o a la Constitución (art. 58, II, $\mathbb{S}$ $1^{\circ}$ ). A tenor de las hipótesis de admisión importadas por la adopción del patrón norteamericano, que tiene como notas básicas la supremacía de la constitución y la independencia del Poder Judicial, se alzó el oficio de controlar la validez de las leyes y de los actos normativos del poder público al nuevo recurso extraordinario patrio, sin prejuicio de la función de velar por la integridad y por la uniformidad del ordenamiento jurídico. En otras palabras, con el writ of error se incorporó al derecho brasileño el judicial review norteamericano, de modo que el Tribunal Supremo Federal también pasó a ejercer el control jurisdiccional de las leyes, a semejanza de la Corte Suprema estadounidense ${ }^{8}$.

6 Instituido durante el período Imperial, el recurso de revista fue el pionero recurso extraordinario brasileño. De acuerdo con la Ley del 18 de septiembre de 1828, la revista consistía en un recurso puesto a disposición de las partes, del Ministerio Público y del Procurador de la Corona y Soberanía Nacional contra las sentencias de todo el órgano judicial que, en última instancia, hubiesen violado la ley al proporcionar una nulidad manifiesta o una injusticia notoria. La concesión de la revista por el Supremo Tribunal de Justicia implicaba la casación de la sentencia y la remesa ex oficio de los autos a un tribunal de relación que la corte designase para nueva resolución de la causa. En verdad, la revista estuvo lejos de desempeñar, efectivamente, el papel concerniente a un recurso de género extraordinario. No era función del Supremo Tribunal de Justicia, así como de cualquier otro órgano judicial imperial, controlar la validez de las leyes o interpretarlas. El Supremo Tribunal de Justicia se limitaba a proferir iudicium rescindens en controversias de Derecho privado, cuya aserción adoptada siquiera vinculaba el tribunal de relación para la cual era remitido para nuevo juicio. El tribunal de relación reapreciaba libremente la causa e incluso podía aplicar el derecho tal como había sido en la sentencia anulada. Y como si fuera diminuta su apocada relevancia, la revista fue substraída de la competencia del Supremo Tribunal de Justicia. Al tener en cuenta la mentalidad de menoscabo al poder judicial, se afianzó el entendimiento de que le era vedado conceder revista porque el artículo 158 de la Constitución del Imperio establecía los tribunales de relación en las provincias como segunda y última instancia. En razón de la contradicción existente en el texto constitucional y, mayormente, por la ideología dominante de la época, el pionero recurso extraordinario brasileño sucumbió y los tribunales de relación de cada provincia pasaron a decidir en última instancia.

7 Véase SILVA, José Afonso da. Do recurso extraordinário no direito processual brasileiro. São Paulo: Revista dos Tribunais, 1963. pp. 29 et seq.

8 El 11 de octubre de 1890, el Gobierno Provisorio de la República expidió el Decreto 848, que organizó la justicia federal. Este decreto no sólo ratificó, sino que amplió los preceptos 
Ratificadas por la Constitución de $1891^{9}$, con la reproducción de las disposiciones del Decreto 510, esas ideas perduran en Brasil hasta hoy en día, lo mismo con la inclusión del control concentrado de constitucionalidad ${ }^{10}$. Aunque no de forma sustancial, considerada la incolumidad de sus funciones y de la competencia para su juicio, el recurso extraordinario sufrió innumerables alteraciones con el paso de los años y acompañó, de manera refleja, la instabilidad política del país y la inconstancia de su Ley Fundamental. Desde su consagración en la Constitución de 1891 hasta la vigente, de 1988, el recurso padeció, en mayor o menor medida, mudanzas en todas las cartas constitucionales promulgadas, más allá de reformas puntuales provenientes del poder constituyente derivado. A despecho de las modificaciones, el Tribunal Supremo Federal permaneció ejerciendo, por medio del recurso extraordinario, la función de asegurar el primado de la Constitución y de uniformizar la aplicación de la legislación federal, así como de controlar la legalidad de las leyes y de los actos normativos ${ }^{11}$.

apuntados en el Decreto 510, con lo cual aproximó más aún el nuevo recurso extraordinario brasileño al writ of error. Allende reafirmar la competencia del Tribunal Supremo Federal para examinar la constitucionalidad de la ley y de los actos de la administración pública por la vía del recurso extraordinario, el Decreto 848 estableció el principio según el cual la magistratura sólo debería interferir en concreto y por provocación de las partes en la protección y en la aplicación de la Constitución y de las leyes federales.

9 El recurso fue acogido por la Constitución Federal de 1891, la primera de la era republicana, aún sin la denominación de extraordinario. El empleo del nombre recurso extraordinario aconteció sólo con la edición del estatuto interno del Tribunal Supremo Federal, en 1891. En el plano constitucional, la adopción de la designación 'extraordinario' principió con la Constitución Federal de 1934.

10 Con el tiempo, el control de constitucionalidad represivo en Brasil pasó a ser mixto. Sin embargo, hasta hoy es por medio del recurso extraordinario que el Tribunal Supremo Federal ejerce, con más frecuencia y efectividad, el control de constitucionalidad. El recurso extraordinario siempre representó el mayor volumen de procesos en las estadísticas de la corte y, en consecuencia, exige su actuación en escala y variedad más significativa en la guarda de la Constitución. Sobre el origen del control jurisdiccional de constitucionalidad en el Derecho brasileño y su ejercicio por el Tribunal Supremo Federal, véanse BARBI, Celso Agrícola. "A evolução do controle de constitucionalidade das leis no Brasil". In: O PODER Judiciário e a Constituição. Porto Alegre, pp. 127 - 149, 1977; DALLARI, Dalmo de Abreu. "O controle de constitucionalidade pelo Supremo Tribunal Federal”. In: O PODER Judiciário e a Constituição. Porto Alegre, 1977, pp. 151 - 183; MENDES, Gilmar Ferreira. Jurisdição constitucional: o controle abstrato de normas no Brasil e na Alemanha. São Paulo: Saraiva, 2005. pp. 64 - 103, 146 - 250, 316 - 413; y MORAES, Alexandre. Jurisdição constitucional e tribunais constitucionais: garantia suprema da constituição. São Paulo: Atlas, 2003. pp. 209 - 308.

11 El recurso extraordinario fue alterado por la Enmienda Constitucional del 3 de septiembre de 1926; las constituciones de 1934; 1937; 1946 y de 1967; y por la Enmienda Constitucional $\mathrm{N}^{\circ}$ 1, del 17 de octubre de 1969. Sobre el origen y la evolución del recurso extraordinario en el Derecho brasileño, véase, por todos, CÔRTES, Osmar Mendes Paixão. Recurso extraordinário: origem e desenvolvimento no direito brasileiro. Rio de Janeiro: Forense, 2005.

ISSN 2346-3473 • pp. 223-249 • Julio - Diciembre de 2016 • Bogotá, D.C. - Colombia 
La transformación de los recursos extraordinarios en el derecho procesal brasileño

\section{El régimen en el orden constitucional vigente}

Promulgada en 1988, la Constitución Federal en vigor llevó a cabo el cambio más significativo en la sistemática del recurso extraordinario desde su institución. Realizó, verdaderamente, un balizamiento en su historia. En razón del número atroz de recursos en el Tribunal Supremo Federal, fruto máxime, del amplio acceso a la instancia extraordinaria y de la desproporcionalidad, siempre creciente, entre la cantidad de recursos y el número de ministros, se instauró una crisis en la corte, que no tenía más capacidad de garantizar la vigencia y la uniformidad de la Constitución, ni tampoco, de las leyes federales ${ }^{12}$. Esa coyuntura insostenible hizo que el constituyente de 1988 atendiese los anhelos de los abogados y de la sociedad. Acogiendo la sugestión de juristas como José Frederico Marques, Seabra Fagundes, Miguel Reale, Alfredo Buzaid, José Afonso da Silva, el constituyente aprobó la creación de una corte superior -el Tribunal Superior de Justicia- para ejercer, a través de un nuevo recurso extraordinario -el recurso especial-, la función de control de legalidad y de correcta interpretación del derecho federal, lo cual alivió la carga de trabajo del Tribunal Supremo Federal ${ }^{13}$.

Con la creación del Tribunal Superior de Justicia, la Constitución de 1988 consagró una escisión en la tradicional competencia del Tribunal Supremo Federal. El constituyente dividió la materia del recurso extraordinario y transformó la corte de más alta jerarquía en tribunal predominantemente constitucional, en la medida en que le restringió la función de velar por la uniformidad de interpretación y por la aplicación del Derecho en temas de naturaleza constitucional. Por otro lado, transfirió a la nueva corte, el Tribunal Superior de Justicia, la competencia para dirimir, como postrera instancia, mediante el recurso especial, las cuestiones atinentes a la hermenéutica y a la aplicación de las leyes federales ${ }^{14}$.

12 Esa crisis del Tribunal Supremo Federal no fue repentina, sino gradual. Sobre las tentativas anteriores que objetivaron el alivio de la carga de procesos de la Corte Suprema brasileña a partir de la década de cuarenta, véase GALVÃO, Ilmar. "O recurso extraordinário no Supremo Tribunal Federal, após a Carta de 1988”. In: Revista da ESMAC, Rio Branco, v. 1, pp. $13-26,1998$.

13 Véase PINTO, Nelson Luiz. Recurso especial para o Superior Tribunal de Justiça: teoria geral e admissibilidade. São Paulo: Malheiros, 1992. p. 47.

14 A la vista, o bien se colocaba un fin a la liberación tan amplia de la instancia extraordinaria o bien se aumentaba el número de jueces. La opción que el CONSTITUYENTE escogió para resolver la llamada crisis del Tribunal Supremo Federal fue la segunda, por medio de la creación de un nuevo tribunal superior, por lo cual decenas de juzgadores pasaron, mediante un nuevo recurso extraordinario, a la ejecución de la tarea de celar por la protección y por la uniformidad del Derecho positivo federal. Esa solución no fue recibida sin ninguna oposición. Las opiniones contrarias se centraron, principalmente, en los problemas oriundos de la dualidad de tribunales incumbidos de rever las mismas decisiones y en la supresión de la competencia del Tribunal Supremo Federal con relación a las cuestiones federales de 
Así, desde 1988 son dos los recursos extraordinarios en el Derecho procesal brasileño. El recurso extraordinario y el recurso especial ejercen una función básicamente federativa, sin abrazar las leyes y los actos normativos estatales, distritales y municipales, cuya competencia para velar por la integridad y unidad corresponde a los órganos jurisdiccionales de las justicias locales, en el ámbito de su respectiva jurisdicción. Ambos recursos son, en esencia, de revisión. Una vez pasado el juicio de admisibilidad, compete al respectivo tribunal superior competente juzgar el caso concreto y sustituir la resolución impugnada, sea para mantenerla o modificarla. Sólo excepcionalmente, cuando hay reconocimiento de nulidad procesal o la necesidad de que sean rectificados actos procesales efectuados en las instancias ordinarias, la corte superior anula la decisión recurrida y se abstiene de resolver el caso.

Dado que contienen base procedimental rígida, los dos recursos constituyen inconformidades de Derecho estricto, sujetos a innúmeros requisitos de admisibilidad, generales y específicos ${ }^{15}$. Las hipótesis de su admisión están estatuidas en la Constitución Federal, respectivamente en el inciso III del artículo 102 y en el inciso III del artículo 105. De acuerdo con el orden constitucional en vigor, el recurso extraordinario es admisible contra las causas resueltas en única o última instancia, cuando la decisión recurrida: a) contraría disposición de la Constitución; b) declara tratado o ley federal inconstitucional; c) juzga válida ley o acto de gobierno local contestado frente a la Constitución; y d) juzga válida ley local contestada frente a la ley federal ${ }^{16}$. Ya el recurso especial es admisible contra las causas resueltas, en

mayor repercusión. Muchos se posicionaron en contra, porque consideraron que el Tribunal Superior de Justicia constituiría una tercera instancia, agraviando aún más la morosidad en los juicios de los procesos, así como también por el recelo de que el nuevo tribunal se constituyese, a fin de cuentas, en un ínterin entre los tribunales locales y el Tribunal Supremo Federal y afectara la autonomía de la justicias estatales.

15 El Tribunal Supremo Federal y el Tribunal Superior de Justicia establecieron, por medio de su jurisprudencia y de sus respectivos estatutos internos, óbices para la admisión de los recursos extraordinario y especial, verbi gratia, la necesidad del previo debate de la cuestión de Derecho vehiculada en recurso por la instancia inferior, la imposibilidad de reexamen de las materias fático-probatorias y el anterior agotamiento de las instancias ordinarias. Acerca de la admisión de los recursos extraordinario y especial, véase MANCUSO, Rodolfo de Camargo. Recurso extraordinário e recurso especial. 13. ed. São Paulo: Revista dos Tribunais, 2015. passim.

16 La hipótesis permisiva de recurso extraordinario inserida en la letra "d" del inciso III del artículo 102 de la Constitución estaba originalmente prevista en el inciso III del artículo 105, como letra "b", y amparaba la interposición de recurso especial. La Enmienda Constitucional No 45, de 2004, trasladó esa hipótesis de admisión para el inciso III del artículo 102, corrigiendo equívoco que ya estaba arraigado en el texto constitucional brasileño. En el sistema federativo de Brasil no existe jerarquía entre la ley local y la ley federal y, en consecuencia, incompatibilidad entre ellas. La discusión alrededor de la aplicación de una u otra ley 
La transformación de los recursos extraordinarios en el derecho procesal brasileño

única o última instancia, por los tribunales regionales federales, por los tribunales de los Estados o por el Tribunal del Distrito Federal y Territorios, cuando la decisión recurrida: a) contraría tratado, ley federal o les niega vigencia; b) juzga válido acto de gobierno local contestado frente a la ley federal; y c) confiere a ley federal interpretación divergente de la que le ha dado otro tribunal ${ }^{17}$.

\subsection{La Enmienda Constitucional 45 y las reformas al anterior Código Procesal Civil}

La incesante creciente demanda por los servicios judiciales y la amplia facilidad para alcanzar el Tribunal Supremo Federal, inclusive en causas repetitivas y sin ninguna relevancia jurídica o social, hicieron que quedase nuevamente incapacitada la Corte Suprema brasileña, esta vez para el ejercicio de su función principal de tutela de la Constitución. Según los datos divulgados por el propio Tribunal Supremo Federal, en el 2000 la corte recibió 105.307 procesos, contra 14.721 procesos en 1989. De 1989 a 2000, a pesar de la fundación del Tribunal Superior de Justicia, el número de procesos recibidos por el Tribunal Supremo Federal aumentó más de $600 \%$. En 2003, entraron en la corte 160.453 nuevos procesos, de los cuales $97,20 \%$ fueron registrados como recursos extraordinarios y agravios de instrumento ${ }^{18}$.

Esa situación resucitó, otra vez, el debate sobre la adopción de medidas para restringir la carga de servicio del Tribunal Supremo Federal, máxime en la vía extraordinaria. No sin razón, después de innúmeras discusiones en los escenarios jurídico y político, fue aprobada en el 2004 la Enmienda Constitucional 45, que, entre otras modificaciones, instituyó la repercusión general de la cuestión constitucional como presupuesto esencial para la admisión de recurso extraordinario (CF, art. $\left.102, \mathbb{3} 3^{\circ}\right)^{19}$.

concierne, en realidad, a las reglas constitucionales que tratan de la repartición de la competencia legislativa entre los entes federados (CF, arts. 23 a 25). De este modo, la cuestión que tiene por objeto juicio fundado en la validez de la ley local contestada a la luz de la ley federal posee, notoriamente, sesgo constitucional, razón por la cual fue correcto el desplazamiento del permisivo para el ámbito del recurso extraordinario, el cual erigió el juicio de esa hipótesis al Tribunal Supremo Federal.

17 El Tribunal Superior de Justicia encabeza la justicia común y asciende a las justicias estatales, la justicia del Distrito Federal y Territorios y la justicia federal no especializada. No tiene competencia para juzgar los recursos oriundos de la justicia especializada, formada en Brasil por las justicias laboral, electoral y militar.

18 Agravio de instrumento era el recurso admisible contra la decisión de presidente o vicepresidente de tribunal local que no aceptaba, en juicio de admisibilidad, recurso extraordinario o recurso especial interpuesto.

19 En Brasil, los tribunales editan súmulas, a saber, enunciados que sintetizan entendimientos jurisprudenciales con eficacia persuasiva. La Enmienda Constitucional № 45 también instituyó 
Ya utilizado en la Constitución precedente y preterido por el constituyente originario, en virtud del inconformismo de influyentes juristas de entonces que sensibilizaran la Asamblea Nacional Constituyente, el instituto de la repercusión general se inspiró en la experiencia estadounidense iniciada en 1925 a través del writ of certiorari, por el cual se otorgó a la Corte Suprema norteamericana el poder de seleccionar, entre millares de recursos, aquellos que eran merecedores de su apreciación al tener en cuenta el alcance y la importancia de las causas. Por el mismo camino sigue la repercusión general de la cuestión constitucional, una vez que el recurrente debe demostrar la repercusión general de la cuestión constitucional aventada en el recurso extraordinario, a fin de que el Tribunal Supremo Federal averigüe si es digna o no de su apreciación ${ }^{20}$.

La repercusión general fue reglamentada por la Ley 11.418, de 2006, que adicionó el artículo 543-A al Código Procesal Civil entonces vigente ${ }^{21}$. Dicha ley aun agregó el artículo 543-B al anterior Código Procesal Civil e instituyó una relevante sistemática para el procesamiento de recursos extraordinarios en causas repetitivas. Cuando existiese multiplicidad de recursos extraordinarios con fundamento en idéntica

el poder del Tribunal Supremo Federal al aprobar súmulas con efecto vinculante, posibilidad reglamentada por la Ley 11.417, de 2006. Con la reglamentación, el Tribunal Supremo Federal pasó a poder aprobar súmula (de oficio o por provocación, mediante la aprobación de dos tercios de sus miembros, después de reiteradas decisiones sobre una materia constitucional), con efecto vinculante en relación a los demás órganos del poder judicial y de la administración pública directa e indirecta, en las esferas federal, estatal y municipal. La llamada súmula vinculante tiene por objetivo la validez, la interpretación y la eficacia de normas constitucionales cuando existe controversia actual entre órganos judiciales, o entre estos y la administración pública, que acarree grave inseguridad jurídica y relevante multiplicación de procesos sobre cuestión idéntica. La reforma constitucional no se olvidó de instituir la posibilidad de cancelación o alteración de las súmulas vinculantes, de esa manera, obsta la inmutabilidad perpetua de sus enunciados. Se estatuyó, de propio, que la aprobación, la revisión o la cancelación de las súmulas vinculantes puede ser provocada por los legitimados a proponer la acción directa de inconstitucionalidad, o sea, el Presidente de la República, la Mesa del Senado Federal, la Mesa da Cámara de los Deputados, las Mesas de Asambleas Legislativas de los Estados, la Mesa de la Cámara Legislativa del Distrito Federal, los Gobernadores de los Estados, el Gobernador de lo Distrito Federal, el Procurador General de la República, el Consejo Federal de la Orden de los Abogados de Brasil, los partidos políticos con representación en el Congreso Nacional, las confederaciones sindicales y las entidades de clase de ámbito nacional.

20 Hay que se reconocer que existe, en su esencia, una contradicción en el mecanismo importado del sistema estadounidense. Si el constituyente eligió determinada materia como merecedora de integrar la Constitución Federal, la ley mayor del país, se presenta contradictorio que el Tribunal Supremo Federal pueda reputarla de menor importancia, de modo a no justificar su actuación mismo ante la existencia de afronta al texto constitucional.

$21 \quad$ Instituido por la Ley 5.869, del 11 de enero de 1973, el anterior Código Procesal Civil estuvo en vigor hasta 17 de marzo de 2016.

ISSN 2346-3473 • pp. 223-249 • Julio - Diciembre de 2016 • Bogotá, D.C. - Colombia 
La transformación de los recursos extraordinarios en el derecho procesal brasileño

controversia, los tribunales de origen deberían seleccionar uno o más recursos representativos de la cuestión, encaminarlos al Tribunal Supremo Federal y sobreseer los demás hasta el pronunciamiento definitivo de la corte.

Pasados dos años, por medio de la Ley 11.672, de 2008, una técnica procesal similar fue establecida en favor de los recursos especiales, en razón del intenso aumento de recursos en el Tribunal Superior de Justicia. Así, cuando hubiese multiplicidad de recursos especiales basados en una idéntica cuestión de Derecho federal, cumplía a los presidentes o vicepresidentes de los tribunales de origen conceder uno o más recursos representativos de la controversia y encaminarlos al Tribunal Superior de Justicia, de esta manera, quedaban suspendidos los demás hasta el pronunciamiento final de la corte.

Más allá de contornar el problema del gran aflujo de procesos que desaguaban en el Tribunal Supremo Federal y en el Tribunal Superior de Justicia, la otorgación de eficacia expansiva a juicios de recursos extraordinarios y especiales implicó una transformación en la naturaleza de los recursos de género extraordinario en Brasil, a través del cual afloraron rasgos objetivos en el ejercicio de su funciones políticas de protección del ordenamiento jurídico. Esta metamorfosis promovida por la Enmienda Constitucional No 45 y las Leyes 11.418 y 11.672 implantó un procedimiento diferenciado para los recursos extraordinarios y especiales repetitivos y se acentuó con el nuevo Código Procesal Civil.

\section{El sistema de los recursos extraordinario y especial con el nuevo Código Procesal Civil}

Por medio de la Ley 13.105, del 16 de marzo de 2015, fue instituido en Brasil un nuevo Código Procesal Civil, cuya vigencia empezó el día 18 de marzo de 2016, una vez superada la vacatio legis de un año.

En líneas generales, se conservó el régimen de los recursos extraordinario y especial. En las hipótesis previstas en la Constitución Federal, los recursos deben ser planteados ante el presidente o vicepresidente del tribunal recurrido, en peticiones distintas que contengan la exposición del hecho y del derecho; la demostración de la pertinencia del recurso; y las razones del pedido de reforma o de invalidación de la decisión recurrida (art. 1.029, caput). El caput del artículo 1.030 disciplina que, una vez recibida la petición del recurso por la secretaria del tribunal local, el recurrido debe ser intimado para presentar respuesta en el plazo de quince días. Finalizado el plazo, los autos son remitidos al presidente o al vicepresidente del tribunal para la elaboración del juicio de admisibilidad ${ }^{22}$. En caso de no ser admitido, el recurrente

22 En el texto original del nuevo Código Procesal Civil, la admisibilidad de los recursos extraordinario y especial sería realizada sólo en la instancia superior. Pero, antes de terminar la vacatio legis, fue editada la Ley 13.256, del 4 de febrero de 2016, que, entre otras providencias sobre el 
puede interponer agravio al respectivo tribunal superior, salvo si la denegación estuviere fundada en la aplicación de entendimiento firmado en régimen de repercusión general o en juzgamiento de recursos repetitivos (art. 1.030, $\mathbb{1} 1^{\circ}$, y art. $1.042)^{23}$.

Admitido el recurso, el proceso es remitido al tribunal superior competente (art. $1.030, \mathrm{~V})$, para que se efectúe nuevo juicio de admisibilidad. Con el designio de evitar el exacerbado formalismo procesal, pasó a ser formalmente permitido al Tribunal Supremo Federal y al Tribunal Superior de Justicia desconsiderar vicios formales de los recursos tempestivos o determinar sus correcciones, desde que estos vicios no sean reputados graves (art. 1.029, $\left.\mathbb{S} 3^{\circ}\right)^{24}$. Concedido el recurso, el tribunal superior juzga el proceso y aplica el derecho al caso concreto (art. 1.034, caput) ${ }^{25}$. Si el recurso fuere concedido por un fundamento, es devuelto el conocimiento de los demás para la solución del capítulo impugnado (art. 1.034, párrafo único). En la hipótesis de interposición conjunta de recursos extraordinario y especial, los autos son remitidos primero al Tribunal Superior de Justicia (art. 1.031, caput) ${ }^{26}$. Concluido el juzga-

procesamiento y juzgamiento de los recursos extraordinario y especial, alteró la redacción del artículo 1.030 del nuevo Código Procesal Civil y restableció el examen de admisibilidad por la corte recurrida, como era en el código anterior.

23 El presidente o vicepresidente del tribunal local no puede admitir recurso extraordinario cuya cuestión constitucional no tenga su repercusión general reconocida por el Tribunal Supremo Federal, así como recurso extraordinario interpuesto contra fallo que esté en conformidad con el entendimiento del Tribunal Supremo Federal pronunciado en el régimen de la repercusión general o de juzgamiento de recursos repetitivos. El presidente o vicepresidente del tribunal local también debe inadmitir recursos especiales interpuestos contra fallos en conformidad con entendimiento del Tribunal Superior de Justicia firmado en régimen de juzgamiento de recursos repetitivos (art. 1.030, I, "a" y "b"). En cualquiera de estos casos se puede interponer agravio interno contra la decisión (art. 1.030, $\$ 2^{\circ}$ ).

$24 \quad$ La Ley 13.256 revocó el $\$ 2^{\circ}$ del artículo 1.029 del nuevo Código Procesal Civil, que había estatuido que sería vedado rehusarse recurso especial fundado en divergencia jurisprudencial con base en el fundamento genérico de que las circunstancias fáticas son diferentes, sin demostrar la existencia de la distinción.

25 En el Tribunal Superior de Justicia, si el relator entiende que el recurso especial versa sobre cuestión constitucional, debe otorgar el plazo de quince días para que el recurrente se manifieste sobre esta y demuestre la existencia de repercusión general. Cumplida dicha diligencia, el relator remete el recurso al Tribunal Supremo Federal, que, en juicio de admisibilidad, puede devolverlo al Tribunal Superior de Justicia (art. 1.032). Por otro lado, si el Tribunal Supremo Federal considera como refleja la ofensa a la Constitución afirmada en el recurso extraordinario, por presuponer la revisión de la interpretación de ley federal o de tratado, lo envía al Tribunal Superior de Justicia para su resolución como recurso especial (art. 1.033).

26 En caso de que se considere perjudicial el recurso extraordinario, el relator del recurso especial sobresee el juicio y remite los autos al Tribunal Supremo Federal para la resolución del recurso extraordinario (art. 1.031, $\mathbb{\$} 2^{\circ}$ ). En resolución irrecurrible, el Tribunal Supremo 
La transformación de los recursos extraordinarios en el derecho procesal brasileño

miento del recurso especial, los autos son enviados al Tribunal Supremo Federal para la apreciación del recurso extraordinario, si este no estuviera perjudicado (art. $\left.1.031, \mathbb{\$} 1^{\circ}\right)$.

El nuevo Código Procesal Civil también regula la posibilidad de concesión ope iudicis de efecto suspensivo a recursos extraordinario y especial. De acuerdo con el $\mathbb{5} 5^{\circ}$ del artículo 1.029 , con la redacción determinada por la Ley 13.256, en el período comprendido entre la interposición del recurso y la publicación de la decisión de admisión del recurso, así como mientras el recurso estuviere sobreseído en el tribunal local por tratarse de recurso repetitivo, el pleito de efecto suspensivo puede ser formulado por requerimiento dirigido al presidente o al vicepresidente del tribunal local. A partir de la publicación del decisum de admisión, la petición de efecto suspensivo debe ser presentada en el respectivo tribunal superior, notablemente al relator si ya fue distribuido el recurso ${ }^{27}$.

Además, cuando se instaura el incidente de resolución de demandas repetitivas ${ }^{28}$, otra novedad del nuevo Código Procesal Civil, al considerar razones de seguridad jurídica o de excepcional interés social, el presidente del Tribunal Supremo Federal o del Tribunal Superior de Justicia puede, a pedido, extender la suspensión de procesos a todo el territorio nacional hasta ulterior decisión del recurso extraordinario o del

Federal puede rechazar la prejudicialidad y devolver los autos al Tribunal Superior de Justicia para que primero juzgue el recurso especial (art. 1.031, $\mathbb{\$} 3^{\circ}$ ).

27 Si no hubo la distribución, el relator designado para el examen del pedido de efecto suspensivo se queda competente para juzgar el recurso extraordinario o especial, conforme el caso (art. $\left.1.029, \$ 5^{\circ}, \mathrm{I}\right)$.

28 Es admisible la instauración de este incidente cuando ha efectiva repetición de procesos con la misma cuestión únicamente de derecho, material o procesal, y existe riesgo de ofensa a la igualdad y a la seguridad jurídica (art. 976). El pedido de instauración del incidente debe ser dirigido al presidente del tribunal, el cual debe ser instruido con los documentos necesarios para demostrar el cumplimiento de los presupuestos para la instauración (art. 977). Luego de la distribución, el órgano colegiado competente para juzgar el incidente de resolución de demandas repetitivas procede a su juicio de admisibilidad (art. 981). Aceptado el incidente, el relator ordena la suspensión de los procesos pendientes, individuales o colectivos, que están tramitando en el Estado o en la región, conforme el caso (art. 982, I). En el juicio, el órgano colegiado competente del tribunal juzga el incidente y fija la tesis jurídica acerca de la cuestión controvertida después del análisis de todos los fundamentos suscitados, favorables o contrarios (art. $984, \mathbb{\$} 2^{\circ}$ ). La tesis jurídica electa debe ser aplicada a todos los procesos que tramitaren en el área de jurisdicción del tribunal originario, incluidos los que tramitan en los juzgados especiales del respectivo Estado o región (art. 985, I). También debe ser aplicada la tesis jurídica a los casos futuros que versaren sobre idéntica cuestión de derecho y vinieren a tramitar en el territorio de competencia del tribunal, a no ser que haya revisión de la doctrina por el mismo tribunal, de oficio o mediante requerimiento de los legitimados a postular su instauración (arts. 985, II, y 986). 
recurso especial a ser interpuesto contra el fallo que juzga el incidente en el tribunal originario (art. 1.029, $\left.\$ 4^{\circ}\right)^{29}$.

Si transcurre in albis el plazo de recursos extraordinario y especial contra la decisión del incidente de resolución de demandas repetitivas, o si no fuere juzgado el mérito del recurso extraordinario o especial eventualmente interpuesto, acaba la suspensión general y la tesis jurídica será aplicada sólo en los procesos en tramitación que versen sobre idéntica cuestión de Derecho en el área de jurisdicción del tribunal de origen que la fijó y a los casos futuros que vinieren a tramitar en el territorio de competencia del tribunal (art. 985) ${ }^{30}$.

Por otro lado, una vez interpuesto recurso extraordinario o especial contra el juicio de mérito del incidente de resolución de demandas repetitivas y al tener este su mérito apreciado, la tesis jurídica adoptada por el Tribunal Supremo Federal o por el Tribunal Superior de Justicia será aplicada en el territorio nacional a todos los procesos individuales o colectivos que versaren sobre idéntica cuestión de Derecho $\left(\right.$ art. $987, \mathbb{\$} 2^{\circ}$ ).

\subsection{Repercusión general de la cuestión constitucional}

La repercusión general pasa a filtrar, de forma preliminar, los recursos extraordinarios en el nuevo Código Procesal Civil.

En conformidad con el artículo 1.035 , caput, $\mathbb{S} \mathbb{S} 2^{\circ}$ y $4^{\circ}$, el Tribunal Supremo Federal no concederá, en decisión irrecurrible, el recurso extraordinario cuando su cuestión constitucional no tuviere repercusión general, cuya existencia debe ser demostrada por el recurrente para la apreciación exclusiva de la Corte Suprema, que puede admitir, en este análisis, la manifestación de terceros, subscrita por procurador habilitado.

Para efecto de repercusión general es considerada la existencia o no de cuestiones relevantes desde el punto de vista económico, político, social o jurídico que ultrapasen los intereses subjetivos del proceso (art. 1.035, $\mathbb{\$} 1^{\circ}$ ). Aunque es

29 Cuando está en discusión en el incidente cuestión constitucional o de derecho federal, cualquiera de los legitimados a postular la instauración del incidente de resolución de demandas repetitivas puede requerir al Tribunal Supremo Federal o al Tribunal Superior de Justicia competente para conocer de eventual recurso extraordinario o especial contra el fallo que juzgare el incidente y la suspensión de todos los procesos en curso en el territorio nacional que versaren sobre la misma cuestión constitucional o infraconstitucional (art. 982, $\mathbb{3}$ ).

30 En caso de que no sea observada la tesis jurídica fijada, tiene lugar la reclamación (art. 985, $\$ 1^{\circ}$ ). Y cuando el incidente tiene por objeto cuestión relativa a la prestación de servicio concedido, permitido o autorizado, el resultado del juicio debe ser comunicado al órgano, al ente o a la agencia reguladora competente para la fiscalización de la efectiva aplicación de la tesis adoptada por parte de los entes sujetos a regulación (art. $985, \mathbb{\$} 2^{\circ}$ ).

ISSN 2346-3473 • pp. 223-249 • Julio - Diciembre de 2016 • Bogotá, D.C. - Colombia 
La transformación de los recursos extraordinarios en el derecho procesal brasileño

presumida la repercusión general siempre que el recurso extraordinario impugna fallo que contraría súmula o jurisprudencia dominante del Tribunal Supremo Federal o tuviere reconocido la inconstitucionalidad de tratado o de ley federal, en los términos del artículo 97 de la Constitución $\left(\operatorname{art.~1.035,~} \mathbb{\$} 3^{\circ}\right)$.

Identificada la existencia de la repercusión general, el relator determina la suspensión del procesamiento de todos los procesos pendientes en el territorio nacional, individuales o colectivos, que versen sobre la misma cuestión constitucional (art. 1.035, $\left.\$ 5^{\circ}\right)^{31}$. El recurso extraordinario que tuviere la repercusión general reconocida debe ser juzgado en el plazo de un año por el Tribunal Supremo Federal y tiene preferencia sobre los demás procesos, salvo los que envolvieren demandado recluso y los pedidos de habeas corpus (art. 1.035, $\mathbb{\$} 9^{\circ}$ ).

Negada la repercusión general, los presidentes o los vicepresidentes de los tribunales de origen deben rehusar los recursos extraordinarios sobreseídos que versaren sobre materia idéntica $\left(\operatorname{art.} 1.035, \mathbb{S} 8^{\circ}\right.$ ).

En cualquier caso, la súmula de la decisión sobre la repercusión general debe constar en acta, la cual debe ser publicada en boletín oficial y valdrá como fallo (art. $1.035, \mathbb{\$} 11)^{32}$.

\subsection{Procesamiento de los recursos repetitivos}

Cuando existe multiplicidad de recursos, extraordinario o especial, con fundamento en idéntica cuestión de derecho, el presidente o el vicepresidente de los tribunales locales debe determinar la suspensión del trámite de todos los procesos pendientes, individuales o colectivos, que estuvieren tramitando en el Estado o en

$31 \quad \mathrm{Al}$ estar sobreseído el recurso extraordinario en el tribunal a quo por tratar de la misma cuestión, cuya repercusión general fue reconocida por el Tribunal Supremo Federal, el interesado puede requerir, al presidente o al vicepresidente del tribunal de origen, que excluya de la decisión de sobreseimiento y no conceda el recurso extraordinario que haya sido interpuesto intempestivamente, así, la parte recurrente tiene el plazo de cinco días para manifestarse sobre ese requerimiento (art. 1.035, $\mathbb{\$} 6^{\circ}$ ). La decisión que desatienda ese requerimiento puede ser impugnada por agravio interno para la misma corte (art. 1.035, $\$ 7^{\circ}$ ).

32 La instauración del incidente de apreciación de la repercusión general y su juicio deben ser sucedidos de la más amplia y específica divulgación y publicidad, por medio de registro electrónico en el Consejo Nacional de Justicia. El Tribunal Supremo Federal debe mantener banco electrónico de datos actualizados con informaciones específicas sobre cada cuestión constitucional cuya repercusión general será analizada, comunicándolos inmediatamente al Consejo Nacional de Justicia para inclusión en los catálogos. Para posibilitar la identificación de los procesos abarcados por las decisiones que apreciaren la existencia de repercusión general, los registros electrónicos de las cuestiones constitucionales deben contener todos los fundamentos de las tesis jurídicas discutidas en las decisiones y las normas constitucionales relacionadas (art. 979, $\mathbb{\$} 3^{\circ}$ ). 
la región, conforme el caso. De igual forma debe seleccionar dos o más recursos representativos de la controversia y encaminarlos al Tribunal Supremo Federal o al Tribunal Superior de Justicia para fines de afectación (art. 1.036, caput y $\left.\mathbb{\$} 1^{\circ}\right)^{33}$. Solamente pueden ser seleccionados recursos admisibles que contuvieren ancha argumentación y discusión respecto de la cuestión (art. 1.036, $\$ 6^{\circ}$ ).

Los escogimientos hechos por presidentes o vicepresidentes de tribunales de justicia o de tribunales regionales federales no vinculan al relator en el tribunal superior, pues él puede seleccionar otros recursos representativos de la controversia (art. 1.036, $\mathbb{S} 4^{\circ}$ ). Independientemente de la iniciativa de los presidentes o vicepresidentes de los tribunales de origen, de acuerdo con el $\mathbb{\$} 5^{\circ}$ del artículo 1.036 del nuevo Código, el relator en el tribunal superior puede elegir dos o más recursos representativos de la controversia para juzgar la cuestión de derecho.

Seleccionados los recursos, el relator dicta la decisión de afectación en el tribunal superior, en la cual debe identificar, con precisión, el tema a ser sometido a resolución y determinar la suspensión del procesamiento de todos los procesos pendientes, individuales o colectivos, en tramitación en el territorio nacional, que versaren sobre el mismo asunto. De este modo, puede solicitar a los presidentes o a los vicepresidentes de los tribunales de justicia o de los tribunales regionales federales la remesa de un recurso representativo de la controversia (art. 1.037,

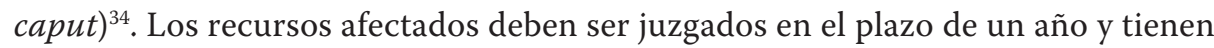
preferencia sobre los demás procesos, salvo los que envolvieren demandado preso y los pedidos de habeas corpus (art. 1.037, $\left.\$ 4^{\circ}\right)^{35}$.

A la luz del caput del artículo 1.038, el relator puede solicitar o admitir la manifestación de personas, órganos o entidades con interés en la controversia, al tener en consideración la relevancia del tema. Con la finalidad de instruir el procedimiento, también puede fijar data para oír declaraciones de personas con

33 Si no procede a la afectación de los recursos, el relator, en el tribunal superior, comunica el hecho al presidente o al vicepresidente que los había enviado, para que sea revocada la decisión de suspensión (art. 1.037, $\mathbb{\$} 1^{\circ}$ ).

34 Las partes deben ser intimadas de la decisión de suspensión de su proceso, permitiéndoles requerir su proseguimiento si demostraren la distinción entre la cuestión a ser decidida en su proceso y la cuestión a ser juzgada en el recurso afectado, sea extraordinario o especial. Ese requerimiento debe ser direccionado al juez de la causa, si el proceso sobreseído estuviere en primer grado; al relator, si el proceso sobreseído estuviere en el tribunal de origen; al relator de la decisión recurrida, si estuviere sobreseído recurso especial o recurso extraordinario en el tribunal de origen; y al relator, en el tribunal superior, de recurso especial o de recurso extraordinario cuyo procesamiento hubiere sido sobreseído (art. 1.037, $\$ \$ 8^{\circ}$ a 10).

35 Por fuerza del $\$ 3^{\circ}$ del artículo 979 del nuevo Código Procesal Civil, también la afectación y el juicio de recursos extraordinario o especial repetitivos deben ser sucedidos de la más amplia y específica divulgación y publicidad.

ISSN 2346-3473 • pp. 223-249 • Julio - Diciembre de 2016 • Bogotá, D.C. - Colombia 
La transformación de los recursos extraordinarios en el derecho procesal brasileño

experiencia y conocimiento en la materia en audiencia pública y solicitar informaciones a los tribunales inferiores con respecto de la controversia. Luego de la manifestación del ministerio público y del envío de copia del relato a los demás ministros, se señala el día para la votación y fallo, el cual debe ocurrir con preferencia sobre los demás procesos $\left(\operatorname{art} .1 .038, \mathbb{\$} 2^{\circ}\right.$ ).

Decididos los recursos afectados, los órganos colegiados declaran perjudicados los demás recursos que versan sobre idéntica controversia o los deciden al aplicar la tesis establecida (art. 1.039, caput) ${ }^{36}$. Publicado el fallo paradigma, y al abarcar el análisis de todos los fundamentos relevantes de la tesis jurídica discutida, los procesos suspendidos en primero y segundo grados de jurisdicción retoman el curso para el juicio y la aplicación de la orientación fijada (art. 1.038, $\mathbb{\$} 3^{\circ}$, y art. $1.040, \mathrm{III})^{37}$.

Los presidentes o vicepresidentes de los tribunales de origen deben rechazar los recursos especiales o extraordinarios sobreseídos si los fallos recurridos coincidieren con la doctrina estipulada por el tribunal superior (art. 1.040, I). Cuando la contrariaren, los propios órganos jurisdiccionales que dictaron los fallos recurridos en el origen reexaminarán sus decisiones anteriores (art. 1.040, II). En el caso de que sea mantenido el fallo divergente por el tribunal de origen, el recurso especial o extraordinario es remitido al respectivo tribunal superior competente (art. 1.041,

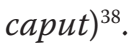

Realizada la retractación, la corte de origen debe decidir, si fuere el caso, las demás cuestiones aún no decididas, cuyo enfrentamiento se hiciere necesario en virtud de la alteración del fallo originario (art. 1.041, $\mathbb{\$} 1^{\circ}$ ). A continuación del reexamen por el órgano de origen, cabe al presidente del tribunal local proceder el juicio de admisibilidad y determinar el envío del recurso al tribunal superior para el juzgamiento de las cuestiones reminiscentes si conocido fuere, a despecho de ratificación del recurso por el recurrente (art. 1.041, $\mathbb{\$} 2^{\circ}$ ).

36 Tratándose de recursos extraordinarios, si fuere negada la existencia de repercusión general en el recurso afectado, son considerados automáticamente inadmisibles los recursos extraordinarios cuyos procesamientos hubieren sido sobreseídos (art. 1.039, párrafo único).

37 Si el recurso extraordinario o especial versan sobre cuestión relativa a la prestación de servicio público objeto de concesión, permisión o autorización, el resultado del juicio debe ser comunicado al órgano, al ente o a la agencia reguladora competente para la fiscalización de la efectiva aplicación de la tesis por parte de los entes sujetos a la regulación (art. 1.040, IV).

38 Consonante con el $\$ 5^{\circ}$ del artículo 988 de nuevo Código, con la redacción determinada por la Ley 13.256, mientras no estén agotadas las instancias ordinarias, es inadmisible la reclamación para los tribunales superiores a fin de garantizar la observancia de fallo de recurso extraordinario con repercusión general reconocida o de fallo dictado en juzgamiento de recursos extraordinario o especial repetitivos. 
Handel Martins Dias

\section{La ampliación de la eficacia expansiva de los juicios}

En los sistemas jurídicos de tradición romano-germánica, la jurisprudencia históricamente conservó un papel secundario. Sin ser considerada, en rigor, auténtica fuente del Derecho, como máximo se le reconocía una fuerza persuasiva. Frente a la rígida separación de poderes de matriz francesa, así como a la concepción dualista del ordenamiento jurídico (que rechaza la función creativa de la sentencia, la cual se limitaría a declarar derechos subjetivos preexistentes), se negaba el carácter impositivo de los precedentes judiciales. Poco a poco, esa tradición viene transformándose en los países de ordenamientos de civil law, entre los cuales Brasil no es una excepción. En el ordenamiento jurídico brasileño, hubo una evolución significativa de los mecanismos de vinculación de la jurisprudencia, desde las primeras disposiciones acerca de la eficacia erga omnes de las decisiones del Tribunal Supremo Federal en control concentrado de constitucionalidad hasta las reformas, en las últimas décadas, del anterior Código Procesal Civil y de la Constitución Federal, que incluso permitía la edición de súmulas vinculantes ${ }^{39}$.

En la vía de los recursos extraordinario y especial, las decisiones del Tribunal Supremo Federal y del Tribunal Superior de Justicia se mantuvieran prácticamente incólumes a esa transformación hasta mediados de la década pasada. La primera ley a modificar ese cuadro fue la Ley 11.418, de 2006, que reglamentó el instituto de la repercusión general al acrecer los artículos 543-A y 543-B en el precedente Código Procesal Civil. Con la reforma, la decisión del Tribunal Supremo Federal, que reconocía la existencia o la inexistencia de la repercusión general de una cuestión constitucional objeto de un determinado recurso extraordinario, valía para todos los demás recursos extraordinarios sobre la misma cuestión constitucional. La decisión que la negaba tenía efecto vinculante, en el plan horizontal y vertical. De acuerdo con el $\$ 5^{\circ}$ del artículo 543-A, esa decisión denegatoria valía para todos los recursos extraordinarios sobre materia idéntica, los cuales debían ser repelidos de pronto, salvo revisión de la tesis.

39 Cf. CABRAL, Antonio do Passo. "A técnica do julgamento-alerta na mudança de jurisprudência consolidada". In: Revista de Processo, São Paulo, Revista dos Tribunais, v. 38, n. 221, pp. 13 - 48, jul. 2013. Véanse también, TUCCI, José Rogério Cruz e. Precedente judicial como fonte do direito. São Paulo: Revista dos Tribunais, 2004; y TUCCI, José Rogério Cruz e. "Variações sobre precedentes judiciais vinculantes e persuasivos". In: O advogado, a jurisprudência e outros temas de processo civil. São Paulo: Quartier Latin, 2010. pp. 67 - 82. Para contraposición a esa tendencia del proceso civil brasileño, véase PICARDI, Nicola; NUNES, Dierle José Coelho. "O Código de Processo Civil brasileiro: origem, formação e projeto de reforma”. In: Revista de Informação Legislativa. Brasília, v. 48, n. 190, pp. 93 - 120, t. II, abr./ jun. 2011.

ISSN 2346-3473 • pp. 223-249 • Julio - Diciembre de 2016 • Bogotá, D.C. - Colombia 
La eficacia expansiva del decisum que no reconocía la existencia de la repercusión general de cuestión constitucional era aún más robusta cuando se daba en recurso extraordinario repetitivo. Conforme el $\$ 2^{\circ}$ del artículo 543-B del Código Procesal Civil anterior, negada la existencia de la repercusión general, los recursos extraordinarios sobreseídos se consideraban automáticamente no concedidos, o sea, ni siquiera existía necesidad de pronunciamiento de juicio de admisibilidad para inadmitirlos.

Sin embargo, la Ley 11.418 no otorgó eficacia expansiva de carácter imperativo a las decisiones del Tribunal Supremo Federal sobre el mérito de las cuestiones constitucionales objeto de los recursos extraordinarios, sino sobre la existencia o no de la repercusión general. No obstante, dio más intensidad a la fuerza persuasiva de sus decisiones. La Ley 11.418 instituyó el procedimiento para el juicio de los recursos extraordinarios repetitivos. En síntesis, los recursos extraordinarios con fundamento en idéntica controversia deberían ser sobreseídos en los tribunales de origen hasta el pronunciamiento definitivo del Tribunal Supremo Federal sobre la materia. Pronunciada la decisión por la corte, los recursos sobreseídos deberían ser apreciados en el origen. Los tribunales locales podían declararlos perjudicados, si ya estuviesen alineados a la orientación precisada por el Tribunal Supremo Federal, o retractarse, si el fallo estuviese en desacuerdo con el pronunciamiento. Como no había efecto vinculante, si no hubiese juicio de retractación, el recurso extraordinario debería ser procesado, situación en la cual el Tribunal Supremo Federal podría revocar o reformar inmediatamente el fallo contrario a su orientación establecida.

Sistemática semejante fue creada en seguida para el recurso especial por la Ley 11.672, de 2008, que reformó el anterior Código Procesal Civil. El procedimiento para el juicio de los recursos especiales repetitivos tuvo el propósito de disminuir el excesivo número de recursos especiales en el Tribunal Superior de Justicia.

Más allá de perfeccionar y sofisticar el sistema procesal en la instancia extraordinaria, el nuevo Código Procesal Civil de Brasil amplió, de forma significativa, la eficacia de las decisiones del Tribunal Supremo Federal y del Tribunal Superior de Justicia en lo tocante a los recursos de género extraordinario.

El principal destaque se centra en la eficacia vinculante de los juicios de mérito en el régimen de los recursos extraordinario y especial repetitivos. A tenor del caput del artículo 1.039 del nuevo Código Procesal Civil, decididos los recursos afectados, los órganos colegiados deben declarar perjudicados los demás recursos y versar sobre idéntica controversia o decidirlos aplicando la tesis fijada. El efecto vinculante es reforzado en el caput del artículo 1.040 del Código, in verbis:

Art. 1.040. Publicado o acórdão paradigma:

I - o presidente ou o vice-presidente do tribunal de origem negará seguimento aos recursos especiais ou extraordinários sobrestados na origem, se o acórdão recorrido coincidir com a orientação do tribunal superior; 
II - o órgão que proferiu o acórdão recorrido, na origem, reexaminará o processo de competência originária, a remessa necessária ou o recurso anteriormente julgado, se o acórdão recorrido contrariar a orientação do tribunal superior;

III - os processos suspensos em primeiro e segundo graus de jurisdição retomarão o curso para julgamento e aplicação da tese firmada pelo tribunal superior;

IV - se os recursos versarem sobre questão relativa à prestação de serviço público objeto de concessão, permissão ou autorização, o resultado do julgamento deverá ser comunicado ao órgão, ao ente ou à agência reguladora competente para fiscalização da efetiva aplicação, por parte dos entes sujeitos a regulação, da tese adotada.

En suma, al atribuirles fuerza vinculante, el legislador tornó precedentes las resoluciones del Tribunal Supremo Federal y del Tribunal Superior de Justicia que juzgan el mérito de los recursos extraordinario y especial repetitivos.

\subsection{La posibilidad de eficacia expansiva a juicios de recursos extraordinario y especial interpuestos en incidentes de resolución de demandas repetitivas}

El segundo alargamiento fundamental de la eficacia de las decisiones en la vía de los recursos extraordinario y especial se dio en el ámbito del incidente de resolución de demandas repetitivas.

El nuevo Código Procesal Civil prevé que, al ser apreciado el mérito del recurso extraordinario o del recurso especial interpuesto contra el juicio de mérito del incidente de resolución de demandas repetitivas, la tesis jurídica adoptada por el Tribunal Supremo Federal o por el Tribunal Superior de Justicia debe ser aplicada en el territorio nacional a todos los procesos individuales o colectivos que versen sobre la misma cuestión de derecho (art. 987, $\$ 1^{\circ}$ ). Por lo tanto, también acá el nuevo Código Procesal Civil está confiriendo efecto vinculante, en todo el país, a las decisiones de las dos cortes de cúpula de la estructura judicial brasileña en la vía de los recursos extraordinario y especial.

En esa conjetura de juicio por muestreo con eficacia vinculante extensiva es de esencial importancia la definición de los procesos y de los recursos por los cuales se fijan las tesis jurídicas que se replicarán en todos los demás procesos y versarán sobre las mismas cuestiones de derecho. La instauración del incidente de resolución de demandas repetitivas a partir de proceso, cuyo argumento favorezca determinada tesis jurídica o la afectación de recursos repetitivos que no permitan el pleno ejercicio cognitivo sobre la cuestión de derecho, entre tantas otras hipótesis, compromete los juicios y, como consecuencia, las fijaciones de la tesis. 
La transformación de los recursos extraordinarios en el derecho procesal brasileño

Con respecto al incidente de resolución de demandas repetitivas, el nuevo Código Procesal Civil no estableció ningún requisito para la causa de dar origen a su instauración. Solamente prescribe que las partes, el ministerio público, la defensoría pública, el juez de la causa en la primera instancia o el relator en el tribunal pueden postular la instauración del incidente cuando hubiere efectiva repetición de procesos que contengan controversia sobre una misma cuestión, únicamente de derecho y riesgo de ofensa a la igualdad y a la seguridad jurídica (arts. 976 y 977). De tal manera, en una interpretación restrictiva, es posible dar origen al incidente a partir de cualquier proceso, esté o no bien delineada la divergencia ${ }^{40}$.

También en el plan subjetivo tienen consecuencias los procesos en que se originan los incidentes, dado que el nuevo Código Procesal Civil confiere notorio protagonismo a las partes de la causa piloto. Ellas deben ser oídas por el relator del incidente y pueden requerir el ingreso de documentos en los autos, la realización de diligencias para la elucidación de la cuestión de derecho debatida y sostener oralmente sus razones, en la sesión de juicio del incidente, por el tiempo de treinta minutos (arts. 983 y 984). Estas, juntamente con el ministerio público y el amicus curiae, son las partes del proceso originario que tienen legitimidad para interponer recurso extraordinario o recurso especial contra el fallo del incidente (art. 138, $\mathbb{\$} 2^{\circ}$, y art. 996). Al tener este recurso su mérito juzgado por el Tribunal Supremo Federal o por el Tribunal Superior de Justicia, se determina la tesis jurídica que será aplicada en el territorio nacional a todos los procesos, individuales o colectivos, atinentes a la misma cuestión de derecho (art. 987).

\subsection{La necesidad de legitimación de los precedentes dictados en recursos extraordinario y especial}

No fue tan negligente el legislador en el ámbito de los recursos extraordinario y especial repetitivos. En la misma línea del precedente, el nuevo Código Procesal Civil no limita la selección a un único recurso extraordinario o especial y establece, como requisito para el escogimiento, que los recursos sean representativos de la controversia.

Con todo, el nuevo Código Procesal Civil avanza en relación al anterior. Primero, dio algún contorno al término "recurso representativo de la controversia" y estatuyó

40 Subraya Antonio do Passo Cabral que, al escoger para afectación un proceso inadecuado en la instauración del incidente de resolución de demandas repetitivas, la decisión del incidente puede no venir a ser la mejor solución de la controversia de masa, con evidente impacto sistémico deletéreo por la multiplicación de la conclusión a todos los otros procesos que tratan de idéntica materia. Cuando existen litigantes habituales, que pueden estratégicamente optar por uno de muchos procesos para provocar el incidente, es posible direccionar la cognición en favor del interés que se desea ver prevalecer. 
que solamente pueden ser escogidos recursos admisibles que comprendan amplia argumentación y discusión al respecto de la cuestión a ser decidida (art. 1.036, $\mathbb{S}$ $\left.6^{\circ}\right)^{41}$. Además, quedó claro que la iniciativa debe ser compartida entre el relator en el tribunal superior y los presidentes o los vicepresidentes de los tribunales de origen (art. 1.036, $\mathbb{S S} 1^{\circ}$ y $5^{\circ}$ ). En reconocimiento a la relevancia de la representatividad de los recursos, el nuevo Código prevé que el relator, en el Tribunal Supremo Federal o en el Tribunal Superior de Justicia, no está compelido a la selección hecha por presidente o vicepresidente del tribunal originario, lo cual le asegura la prerrogativa de elegir otros recursos representativos sobre la materia (art. 1.036, $\$ 4^{\circ}$ ). Más allá de eso, garantiza que el relator puede solicitar, en la decisión de afectación, a los presidentes o vicepresidentes de todos los tribunales de la justicia común, que le remitan, cada uno, un recurso representativo (art. 1.037, III).

Con relación al desarrollo del procedimiento, en vez de conferir protagonismo a las partes de los recursos afectados, el nuevo Código Procesal Civil prefirió apostar en un proceso más dialógico. Antes del juicio, en el cual se impone el análisis de todos los fundamentos relevantes de la tesis jurídica discutida, el relator puede solicitar o admitir la manifestación de personas, órganos o entidades con interés en la controversia, al considerar la relevancia de la materia sub judice, así como fijar fecha para oír personas con experiencia y conocimiento en la materia en audiencia pública. El relator aun debe requerir informaciones a los tribunales inferiores al respecto de la controversia y oír al ministerio público (art. 1.038).

En definitiva, el sistema de procesamiento de los recursos extraordinario y especial repetitivos debería haber sido observado por el legislador cuando trazó el incidente de resolución de demandas repetitivas. De delante, el incidente no podría ser instaurado a partir de cualquier proceso, sino de alguno que sea, de hecho, representativo de la controversia sobre la materia a ser apreciada por el tribunal. Su decisión tiene eficacia vinculante que puede ser extendida a todo el territorio nacional por el Tribunal Supremo Federal o por el Tribunal Superior de Justicia si fuere interpuesto recurso extraordinario o recurso especial (art. 987). A consecuencia de la potencial eficacia de la decisión del incidente, la representatividad de la divergencia debería constituir requisito para el proceso originarlo. En tal sentido, la decisión de instauración del incidente debería ser adecuadamente fundamentada e indicar no sólo la existencia de múltiples procesos que contienen

${ }^{41}$ El nuevo Código fue al encuentro de la Resolución 8, del 7 de agosto de 2008, editada por el Tribunal Superior de Justicia después de la edición de la Ley 11.672, de 2008, que instituyó el procedimiento para el juicio de recursos especiales repetitivos en el entretanto de vigencia del Código Procesal Civil anterior. El $\mathbb{1} 1^{\circ}$ del artículo $1^{\circ}$ de la Resolución 8 prescribe que deberían ser seleccionados solamente los recursos especiales que contenían mayor diversidad de fundamentos en el fallo y de argumentos en el recurso especial.

ISSN 2346-3473 • pp. 223-249 • Julio - Diciembre de 2016 • Bogotá, D.C. - Colombia 
La transformación de los recursos extraordinarios en el derecho procesal brasileño

discusión sobre la misma cuestión de derecho y de riesgo de ofensa a la igualdad y a la seguridad jurídica (art. 976), sino también las razones por las cuales el proceso que establece el incidente bien representa la controversia.

Otrosí, para permitir una visión más amplia y plural, se podría haber permitido la selección, por el relator, de otros procesos sobre la idéntica cuestión y vincularlos al incidente, así como la posibilidad de que otros procesos fuesen indicados por otros miembros del tribunal en donde se instaura el incidente o, el mismo, según el caso, por jueces de la primera instancia.

La ampliación del debate es fundamental para la legitimidad de la decisión. De ahí la importancia de permitirse, al máximo posible, la participación de amicus curiae y la realización de la audiencia pública (arts. 983, 984 y 1.038). Cuanto más amplificado fuere el contradictorio y el debate de argumentos, más capacitado estará el tribunal para decidir sobre la tesis jurídica a ser fijada.

Por lo menos en el ámbito de los recursos extraordinario y especial repetitivos, el legislador estableció alguna dirección para definir lo que sería la representación de una controversia, al prescribir que sólo pueden ser seleccionados recursos admisibles contenedores de extensa argumentación y discusión al respecto de la cuestión controvertida (art. 1.036, $\mathbb{\$} 6^{\circ}$ ). Son los recursos con la mayor cantidad y diversidad de argumentos posibles, de modo que abarquen todos los puntos de vista potencialmente condicionantes de aquel debate: criterio, a propósito, que también debiera ser observado en la instauración del incidente de resolución de demandas repetitivas.

Todavía, para definir con mayor precisión lo que es la representación de la controversia en las causas repetitivas, líneas más nítidas deben ser trazadas por la doctrina, por la jurisprudencia y por los tribunales superiores mediante resoluciones o la revisión de sus respectivos estatutos internos.

Conforme había anticipado Antonio do Passo Cabral, también debe ser considerada la cualidad de las argumentaciones y la efectividad del contradictorio de las causas. Si la línea argumentativa de los litigantes originarios sirve como confrontación dialéctica entre las tesis antagónicas, la cualidad de las alegaciones debe importar, asimismo, para la elección de la causa piloto, así como el análisis por el órgano judicial de todos esos argumentos. En el plan subjetivo, no puede haber desigualdad material entre las partes, especialmente en la perspectiva de la representación procesal. En realidad, cuanto mayor la pluralidad y la representatividad de las partes y de eventuales terceros intervinientes, más calificado será el proceso o recurso como causa piloto. En ese sentido, se muestran más habilitadas para la afectación, en la esfera subjetiva, las demandas colectivas en comparación con las individuales, puesto que son movidas por entes públicos y privados con legitimación extraordinaria concedida por ley para actuar como sustitutos procesales de colectividades. Como esos entes ya poseen la prerrogativa procesal de conducir procesos 
en que, al final, la decisión pueda tener impacto masivo, su presencia en el incidente o en el recurso repetitivo afectado atribuye al contradictorio mayor legitimidad política y social ${ }^{42}$.

\section{Conclusiones}

Desde 2006, aún durante la vigencia del precedente Código Procesal Civil, hubo una transformación de los recursos de género extraordinario en el Derecho procesal brasileño. Al adquirir naturaleza más objetiva, los recursos extraordinarios y especiales pasarán a proporcionar decisiones de eficacia expansiva.

Esta metamorfosis se acentuó con el nuevo Código Procesal Civil, que amplió esta eficacia y le confirió carácter vinculante. Más perfeccionado, el sistema procesal en la instancia extraordinaria tuvo como principal mudanza la concesión de efecto vinculante a los juicios de mérito del Tribunal Supremo Federal y del Tribunal Superior de Justicia en la vía de los recursos extraordinario y especial repetitivos y de los recursos extraordinario y especial, interpuestos contra juzgamientos de tribunales en incidentes de resolución de demandas repetitivas.

Frente a la repercusión sistémica que representa ese cambio de técnica procesal, el cual otorga eficacia vinculante expansiva a juicios de recursos extraordinario y especial por muestreos, es de fundamental importancia la definición de los procesos y de los recursos por los cuales se fijan las tesis jurídicas que se multiplican en todos los demás procesos que comprenden las mismas cuestiones de derecho. Sólo los procesos y los recursos que fueren, de hecho, representativos de la controversia pueden servir para la instauración del incidente de demandas repetitivas o para la afectación como repetitivos.

En el plan objetivo, la representación de la controversia se traduce por la mayor cantidad, diversidad y calidad de argumentos alrededor de la cuestión de derecho controversial, debidamente debatidos y enfrentados en los procesos o en los recursos mediante efectivo contradictorio. En el plan subjetivo, la representación de la controversia se revela por la equidad de las partes y de eventuales intervinientes en los procesos o en los recursos, así como por su mayor pluralidad y representatividad, en la que se destacan los entes con legitimidad extraordinaria conferida por ley para actuar como sustitutos procesales en la defensa de derechos e intereses metaindividuales.

42 Véase CABRAL, "Antonio do Passo. A escolha da causa-piloto nos incidentes de resolução de processos repetitivos". In: Revista de Processo, São Paulo, Revista dos Tribunais, v. 39, n. 231, pp. 201 - 223, maio 2014.

ISSN 2346-3473 • pp. 223-249 • Julio - Diciembre de 2016 • Bogotá, D.C. - Colombia 
La transformación de los recursos extraordinarios en el derecho procesal brasileño

\section{Referencias bibliográficas}

BARBI, Celso Agrícola. "A evolução do controle de constitucionalidade das leis no Brasil”. In: O PODER Judiciário e a Constituição. Porto Alegre, 1977.

CABRAL, Antonio do Passo. "A escolha da causa-piloto nos incidentes de resolução de processos repetitivos". Revista de Processo, São Paulo, Revista dos Tribunais, v. 39, n. 231, maio 2014.

....-. "A técnica do julgamento-alerta na mudança de jurisprudência consolidada”. Revista de Processo, São Paulo, Revista dos Tribunais, v. 38, n. 221, jul. 2013.

CALAMANDREI, Piero. La cassazione civile. Milano: Fratelli Bocca, 1920. 2v.

CANARIS, Claus-Wilhelm. Pensamento sistemático e conceito de sistema na ciência do direito. Tradução A. Menezes Cordeiro. Lisboa: Calouste Gulbenkian, 2002.

CÔRTES, Osmar Mendes Paixão. Recurso extraordinário: origem e desenvolvimento no direito brasileiro. Rio de Janeiro: Forense, 2005.

DALLARI, Dalmo de Abreu. "O controle de constitucionalidade pelo Supremo Tribunal Federal”. In: O PODER Judiciário e a Constituição. Porto Alegre, 1977.

DIAS, Handel Martins. Condicionamento histórico do processo civil brasileiro: o legado do direito lusitano. 2015. 389 p. Tese (Doutorado em Direito), Faculdade de Direito, Universidade de São Paulo, São Paulo, 2014.

FABRÍCIO, Adroaldo Furtado. “Os equívocos da reforma do Judiciário”. In: Revista Forense, Rio de Janeiro, Forense, v. 378, mar. / abr. 2005.

GALVÃO, "Ilmar. O recurso extraordinário no Supremo Tribunal Federal, após a Carta de 1988". In: Revista da ESMAC, Rio Branco, v. 1, 1998.

KNIJNIK, Danilo. O recurso especial e a revisão da questão de fato pelo Superior Tribunal de Justiça. Rio de Janeiro: Forense, 2005.

MANCUSO, Rodolfo de Camargo. Recurso extraordinário e recurso especial. 13. ed. São Paulo: Revista dos Tribunais, 2015.

MENDES, Gilmar Ferreira. Jurisdição constitucional: o controle abstrato de normas no Brasil e na Alemanha. São Paulo: Saraiva, 2005.

MIRANDA, Jorge. Manual de direito constitucional. 6v. Coimbra: Coimbra, 2000.

MONTEIRO, Washington de Barros. Do recurso extraordinário. Justitia, São Paulo, Serviço de documentação jurídica do Ministério Público, v. 21, 1958.

MORAES, Alexandre. Jurisdição constitucional e tribunais constitucionais: garantia suprema da constituição. São Paulo: Atlas, 2003.

MOREIRA, José Carlos Barbosa. Comentários ao Código de Processo Civil. v. 5. Rio de Janeiro: Forense, 2004.

PICARDI, Nicola; NUNES, Dierle José Coelho. "O Código de Processo Civil brasileiro: origem, formação e projeto de reforma". In: Revista de Informação Legislativa, Brasília, v. 48, n. 190, t. II, abr. / jun. 2011. 
PINTO, Nelson Luiz. Recurso especial para o Superior Tribunal de Justiça: teoria geral e admissibilidade. São Paulo: Malheiros, 1992.

RODRIGUES, Lêda Boechat. "A Suprema Corte dos Estados Unidos e sua contribuição ao direito constitucional brasileiro". In: O PODER Judiciário e a Constituição. Porto Alegre, 1977.

SILVA, José Afonso da. Do recurso extraordinário no direito processual brasileiro. São Paulo: Revista dos Tribunais, 1963.

TUCCI, José Rogério Cruz e. Precedente judicial como fonte do direito. São Paulo: Revista dos Tribunais, 2004.

-.-.--- "Variações sobre precedentes judiciais vinculantes e persuasivos". In: . O advogado, a jurisprudência e outros temas de processo civil. São Paulo: Quartier Latin, 2010.

ZAVASCKI, Teori Albino. Eficácia das sentenças na jurisdição constitucional. São Paulo: Revista dos Tribunais, 2001. 